\title{
Н. Ю. Голубєва \\ РОЗГЛЯД СУДАМИ СПРАВ ПРО ВИЗНАННЯ ПРАВА ВЛАСНОСТІ НА ОБ'ЄКТИ САМОЧИННОГО БУДІВНИЦТВА
}

Постановка проблеми. Актуальність дослідження особливостей розгляду судами справ, пов'язаних з об'єктами самочинного та незавершеного будівництва, зумовлюється значною кількістю відповідних справ у судах України та неоднаковим застосуванням законодавства, яке регулює особливості користування, володіння та розпорядження об'єктами самочинного будівництва, визнання права власності на них та умови участі у цивільному обігу.

До теми обігу, визнання прав тощо стосовно об'єктів самочинного будівництва представники теорії цивільного права звертаються лише побіжно, коментуючи ст. 376 ЦК України. Більшість досліджень у цій сфері здійснюються практиками, оскільки неврегульованість питання належного способу визнання права власності на ці об'єкти зумовлює значні труднощі на практиці. Адміністративний порядок визнання права власності на об'єкти самочинного будівництва також не задовольняє повною мірою потреби цивільного обороту через складність і тривалість (хоча саме він $є$ правильним, судовий порядок - це виняток). Серед досліджень останніх років варто відзначити праці В. Грабчинської, І. Мацюк, І. Панченко, А. Савченко, В. Литовченко, М. Шульги та ін.

Метою статті $€$ аналіз проблем судової практики під час розгляду судами справ про визнання права власності на об'єкти самочинного будівництва.

Виклад основного матеріалу дослідження. До об'єктів нерухомого майна ЦК України віднесено житлові будинки, будівлі, споруди, інше нерухоме майно (ст.ст. 331, 376). Згідно із Законом України «Про оренду державного та комунального майна» нерухоме майно поділяється на будівлі, споруди, приміщення (ст. 4). Визначення понять «житловий будинок», «квартира», «садиба» містяться у гл. 28 ЦК України, поняття «об'єкти житлової нерухомості» - у Податковому кодексі України. Об'єкти житлової нерухомості поділяються на такі типи: житловий будинок, житловий будинок садибного типу, прибудова до житлового будинку, квартира, котедж, кімнати у багатосімейних (комунальних) квартирах, садовий 
і дачний будинки (ст. 14.1.129). Об’єкти нерухомого майна мають бути капітального типу, а не тимчасовими, що є характерним для малих архітектурних форм і тимчасових споруд для провадження підприємницької діяльності, визначення яких міститься у ст. 28 Закону України «Про регулювання містобудівної діяльності» № 3038-VI від 17 лютого 2011 р. [1].

Не підлягають державній реєстрації речові права та їх обтяження на корисні копалини, рослини, а також на малі архітектурні форми, тимчасові, некапітальні споруди, розташовані на земельній ділянці, переміщення яких можливе без їх знецінення та зміни призначення, а також окремо на споруди, що є належністю головної речі або складовою частиною речі, зокрема на магістральні та промислові трубопроводи (у тому числі газорозподільні мережі), автомобільні дороги, електричні мережі, магістральні теплові мережі, мережі зв'язку, залізничні колії (ч. 4 ст. 5 Закону України «Про державну реєстрацію речових прав на нерухоме майно та їх обтяжень» від 01.07.2004 р.).

Право власності на новостворену нерухому річ (житлові будинки, будівлі, споруди тощо) набувається: а) з моменту завершення будівництва; б) з моменту прийняття нерухомого майна до експлуатації, якщо договором або законом передбачено прийняття нерухомого майна до експлуатації; в) 3 моменту державної реєстрації прав на нерухоме майно, якщо право власності відповідно до закону підлягає державній реєстрації (ст. 331 ЦК України).

Водночас відповідно до ч. 1 ст. 182 ЦК України право власності на нерухомі речі підлягає державній реєстрації. Названа норма має імперативний характер і підлягає пріоритетному застосуванню перед нормами ст. 331 ЦК України. Тому право власності на нерухомі речі може виникати лише з моменту державної реєстраціі.

Основною умовою для визначення статусу нерухомого майна будь-якого об’єкта нерухомості (зокрема, й тих об'єктів, правовий статус яких законодавчими актами не визначений: асфальтовані чи бетонні майданчики, під”ізні колії, автомобільні дороги, автомобільні платформи, спортивні споруди тощо) є державна реєстрація прав на нього [1].

Державна реєстрація права власності здійснюється на підставі Закону України «Про державну реєстрацію речових прав на нерухоме майно та їх обмежень» від 1 липня 2004 р. у редакції від 26.11.2015 р. та Постановою Кабінету Міністрів України «Про державну реєстрацію речових прав на нерухоме майно та їх обтяжень» № 1127 від 25 грудня 2015 р. Процедура прийняття об'єкта в експлуатацію регламентована Порядком прийняття в експлуатацію закінчених будівництвом об’єктів, затвердженому Постановою Кабінету Міністрів України № 461 від 13 квітня 2011 р. (у редакції Постанови Кабінету Міністрів України № 750 від 8 вересня 2015 р.).

Прийняття в експлуатацію закінчених будівництвом об’єктів здійснюється на підставі сертифіката відповідності, що видається Держархбудінспекцією та іï територіальними органами.

На закінченому будівництвом об'єкті повинні бути виконані всі передбачені проектною документацією та державними стандартами, будівель- 
ними нормами і правилами роботи, а також змонтоване і випробуване обладнання.

Вказана процедура застосовується тоді, коли об'єкт нерухомості збудований з отриманням дозволу на будівництво.

Якщо об’єкт збудований без отримання відповідного дозволу, то має застосовуватися Наказ Міністерства регіонального розвитку, будівництва та житлово-комунального господарства «Про затвердження Порядку прийняття в експлуатацію і проведення технічного обстеження індивідуальних (садибних) житлових будинків, садових, дачних будинків, господарських (присадибних) будівель і споруд, громадських будинків та будівель і споруд сільськогосподарського призначення I та II категорій складності, які збудовані без дозволу на виконання будівельних робіт» № 79 від 24.04 .2015 р. (йдеться про прийняття в експлуатацію об'єктів самочинного будівництва - ст. 376 ЦК України).

Самочинним будівництвом $€$ житловий будинок, будівля, споруда, інше нерухоме майно (нове будівництво, реконструкція зі зміною площі та зайняттям земельної ділянки, прибудови, надбудови), якщо: 1) вони збудовані або будуються на земельній ділянці, що не була відведена для цієї мети; 2) без відповідного документа, який дає право виконувати будівельні роботи; 3) без належно затвердженого проекту; 4) з істотними порушеннями будівельних норм і правил.

При цьому для визнання об’єкта самочинним будівництвом досить хоча б однієі підстави. Як правило, у разі самочинного будівництва відсутні відразу два необхідних документи: погоджений проект і дозвіл на здійснення будівництва.

Відсутність у забудовника відводу земельної ділянки під будівництво означає, що забудовник: 1) самовільно зайняв землю; або 2) порушив іiі цільове призначення. У першому випадку йдеться про захоплення земельної ділянки, за ці дії передбачена кримінальна відповідальність відповідно до ст. 197-1 КК України. Порушення забудовником цільового призначення земельної ділянки є більш розповсюдженим випадком.

Будівництвом об’єкта нерухомості на земельній ділянці, що не була відведена для цієї мети, вважається спорудження таких об’єктів на земельній ділянці, що не віднесена до земель житлової і громадської забудови, зокрема, наданій для ведення городництва, сінокосіння, випасання худоби тощо, цільове призначення або вид використання якої не змінено в установленому законом порядку. Під наданням земельної ділянки слід розуміти рішення компетентного органу влади чи органу місцевого самоврядування про передачу земельної ділянки у власність або надання у користування, або передачу права користування земельною ділянкою на підставі цивільно-правових договорів із фізичною чи юридичною особою. При цьому не може вважатися наданням земельної ділянки лише рішення компетентного органу влади про надання дозволу на розробку проекту землеустрою щодо відведення земельної ділянки або для розробки проекту забудови. Під метою надання земельної ділянки слід розуміти вид викори- 
стання земельної ділянки (ст. 19 ЗК України, Класифікація видів цільового призначення земель, затверджена Наказом Державного комітету України із земельних ресурсів № 548 від 23 липня 2010 р.), зазначений у рішенні відповідного компетентного органу державної влади чи місцевого самоврядування про надання земельної ділянки у користування або передачу у власність з урахуванням цільового призначення земельної ділянки [2].

Закон України «Про планування і забудову територій» передбачає обов'язок забудовника підготувати попередньо цілу низку документів, зокрема отримати необхідні документи на земельну ділянку та погодити у відповідних органах проект будівництва. Зрозуміло, що ці вимоги покликані забезпечувати безпеку під час проведення будівельних робіт та експлуатації уже збудованого об'єкта.

Щоб погодити проект будівництва відповідно до норм чинного законодавства, забудовникові необхідно одержати дозвіл міської ради на право розробити й погодити проект, замовити проект у ліцензованій проектній організації, погодити проект з органами санітарного, пожежного й екологічного нагляду, провести експертизу, а потім затвердити проект у міськраді.

Відсутність цих документів означає, що об'єкт нерухомості зводиться самовільно.

До документів, які надають право виконувати будівельні роботи, належать: повідомлення про початок будівельних робіт, реєстрація декларації про початок виконання будівельних робіт, видача технічних умов, видача вихідних даних тощо.

Самочинним також вважається будівництво хоча і на підставі проекту, але за наявності істотних порушень зазначених норм та правил як у самому проекті, так і під час будівництва за наявності рішень спеціально уповноважених органів про усунення порушень [2].

Факт істотного порушення будівельних норм і правил можна встановити шляхом проведення експертизи ліцензованою організацією згідно 3 вимогами ст. 143 ЦПК України. Ці порушення або негативно позначаються на правах третіх осіб, або можуть привести до порушення правил експлуатації об'єкта, зокрема, до псування або загибелі об'єкта нерухомості.

Особа, яка здійснила або здійснює самочинне будівництво нерухомого майна, не набуває права власності на нього.

Право власності на самочинно збудоване нерухоме майно не набувають і спадкоємці забудовників. Права спадкоємців щодо самочинно збудованого майна визначаються судом відповідно до положень статті 1218 ЦК України та з урахуванням роз'яснень, наданих у п. 7 Постанови Пленуму Верховного Суду України «Про судову практику у справах про спадкування» № 7 від 30 травня 2008 р.

Це майно не є об’єктом права власності, воно не може бути предметом поділу та встановлення порядку користування у судовому порядку; на нього не може бути звернено стягнення за виконавчими документами, зокрема продаж його з прилюдних торгів [2]. 
До початку реалізації права на забудову конкретної земельної ділянки особа зобов'язана у встановленому порядку набути право власності або користування на цю земельну ділянку.

Особа, яка здійснила самочинне будівництво об’єкта на земельній ділянці, що не була їй відведена для цієї мети, не може набути право власності на нього в порядку ст. 331 ЦК України.

Водночас законодавством передбачено можливість легалізації самочинної забудови. Право власності на самочинно збудоване нерухоме майно може бути за рішенням суду визнане лише у двох випадках.

По-перше, за особою, яка здійснила самочинне будівництво на земельній діляниі, що не була їй відведена для иієї мети, за умови надання земельної ділянки у встановленому порядку особі під уже збудоване нерухоме майно.

Перешкоди для визнання права власності на самочинно збудоване нерухоме майно вказані у ч. 4 ст. 376 ЦК України: 1) власник (користувач) земельної ділянки заперечує проти визнання права власності на нерухоме майно за особою, яка здійснила, здійснює самочинне будівництво на його земельній ділянці; 2) порушуються права інших осіб.

Якщо ці обставини у наявності, то суд виносить рішення про знесення об’єкта особою, яка здійснила (здійснює) самочинне будівництво, або за їі рахунок. Отримані під час знесення житлового будинку, будівлі або споруди матеріали залишаються у власності особи, яка здійснила самочинне будівництво.

Тому для легалізації самочинно збудованого об’єкта нерухомості необхідно оформити правовий титул на земельну ділянку під уже побудований об'єкт. Така можливість може бути відсутня у зв'язку з правовим режимом категорії земель або з неможливістю переведення забудованої земельної ділянки з однієї категорії земель до другої.

Відповідно до ст. 125 3К України право власності або право постійного користування на земельну ділянку виникає лише після одержання ії власником або користувачем документа, що посвідчує право власності чи право постійного користування земельною ділянкою, та його державної реєстрації, а право оренди земельної ділянки виникає після укладення договору оренди і його державної реєстрації. Розпочинати використання земельної ділянки до встановлення іiі меж у натурі (на місцевості), одержання документа, що посвідчує право на неї, та державної реєстрації забороняється.

Для підтвердження факту самочинного будівництва необхідно провести технічну інвентаризацію об'єкта, що здійснюється бюро технічної інвентаризаціi.

3 аналізу судової практики з відповідних справ можна зробити висновок про такі вимоги задоволення позову про визнання права власності на самочинно збудоване нерухоме майно за особою, яка здійснила самочинне будівництво на земельній ділянці, що не була їй відведена для цієї мети:

1) надання земельної ділянки у встановленому порядку особі під уже збудоване нерухоме майно. Тобто після закінчення будівництва земельну 
ділянку має бути передано у власність цій особі, або надано у користування, або із власником земельної ділянки, на якій розміщено майно, укладено договір суперфіцію відповідно до ії цільового призначення. Вирішуючи справи такої категорії, суд має виходити з того, що надання земельної ділянки під уже збудоване нерухоме майно чи укладення договору суперфіцію може відбутись як до пред’явлення позову до суду, так і після цього. Якщо під час розгляду справи позивачеві відповідно до законодавства України було надано земельну ділянку або укладено договір суперфіцію, то суд має оцінювати зазначені дії відповідача з урахуванням ч. 4 ст. 174 ЦПК України (визнання відповідачем позову) [2];

2) збудований об'єкт не порушує прав третіх осіб;

3) дотримані будівельні норми і правила (до участі у справі залучається Держархбудінспекція для подання відповідних висновків про відповідність побудованого об'єкта вимогам будівельних норм, або факт відповідності чи невідповідності самочинного будівництва вимогам державних будівельних норм і правил може бути також установлений проведеною у рамках розгляду справи будівельно-технічною експертизою;

4) самочинне будівництво було здійснено саме позивачем, що може підтверджуватися договорами підряду, актами прийому-передачі виконаних будівельних робіт тощо;

5) має бути встановлена відповідність об'єкта пожежним і санітарним нормам (надаються висновки уповноважених на те органів).

Належним відповідачем за цією категорією справ $€$ відповідна місцева рада (Закони України «Про місцеве самоврядування на Україні», «Про основи містобудування»).

Якщо самочинно збудоване нерухоме майно на чужій земельній ділянці, то позов про визнання права власності може бути пред’явлено до органу державної влади або органу місцевого самоврядування та власника (користувача) земельної ділянки у разі забудови на земельній ділянці, яка належить до державної чи комунальної власності або фізичній чи юридичній особі. У разі пред'явлення позову про визнання права власності на самочинно збудований об'єкт нерухомості до неналежного відповідача (наприклад, до бюро технічної інвентаризації чи лише до певної фізичної особи) суд залежно від предмета позову та обставин справи у порядку, передбаченому ч. 1 ст. 33 ЦПК України, має вирішити питання про його заміну на належного відповідача або із власної ініціативи у порядку, передбаченому ч. 2 ст. 35 ЦПК України, залучає відповідний державний орган чи орган місцевого самоврядування як третю особу, яка не заявляє самостійних вимог щодо предмета позову, також відповідно до ч. 3 ст. 45 ЦПК України залучає до участі у справі відповідну інспекцію державного архітектурно-будівельного контролю для надання висновків на виконання ii повноважень [2].

Варто відзначити, що власник земельної ділянки, який використав іiі не за цільовим призначенням, здійснивши самочинне будівництво, має у суді набагато більше шансів одержати право власності на такий об'єкт не- 
рухомості, аніж власник земельної ділянки, що, не змінюючи ії цільового призначення, самочинно побудував об'єкт.

Право власності у порядку, передбаченому ч. 3 ст. 376 ЦК України, може бути визнано лише на новозбудоване нерухоме майно або нерухоме майно, яке створено у зв'язку зі знесенням попередньої будівлі та відповідно до будівельних норм і правил є завершеним будівництвом. Визнання права власності на незавершений об'єкт самочинного будівництва не допускається [2].

По-друге, за власником (користувачем) земельної ділянки, на якій здійснено самочинне будівництво, за умов: по-перше, особа - власник земельної ділянки не збігається з особою-забудовником (ця умова найчастіше порушується судами внаслідок неправильного тлумачення положень ст. 376 ЦК України, визнається право власності на самочинні будівлі за власниками земельних ділянок, навіть якщо ці власники є одночасно забудовниками); по-друге, це не порушує права інших осіб. У такому разі видатки, понесені на самочинну побудову об’єкта, підлягають відшкодуванню забудовнику власником (користувачем) земельної ділянки.

Таким чином, на вимогу власника (користувача) земельної ділянки суд може визнати за ним право власності на нерухоме майно, яке самочинно збудоване на ній, якщо це не порушує права інших осіб. Це положення часто у судовій практиці тлумачиться як можливість забудовника, якщо він $є$ власником земельної ділянки, визнати за ним право власності на об'єкт будівництва. На цій підставі «узаконено» велику кількість об’єктів.

Практика, що склалася про визнання права власності на об’єкт за власником земельної ділянки, якщо він сам був забудовником, зумовлена недосконалістю організаційно-правового механізму реалізації права власників земельних ділянок на їхню забудову, що виражається у тривалості процедури одержання дозволу на будівництво, підготовки і затвердження проектної документації, одержання дозволу на виконання будівельних робіт, оформлення права власності на завершене будівництво, а також фінансовими витратами на виконання проектних, юридичних та інших робіт. Процес оформлення може тривати не один рік, тому на практиці визнання права власності на наявні будови здійснювалось у судовому порядку.

Таким чином, забудовники змушені спочатку зводити об'єкт, а потім звертатись у суд. Однак системний аналіз ч.ч. 3-5 ст. 376 ЦК України дозволяє зробити висновок, що законодавець мав на увазі можливість визнання права власності на об'єкт, якщо особа власника (користувача) земельної ділянки не збігається з особою-забудовником. Тобто, якщо під уже збудований об'єкт забудовнику не вдалося відвести земельну ділянку чи змінити іiі цільове призначення, власнику земельної ділянки надається право вимагати, щоб право власності на самочинно збудоване нерухоме майно було визнане за ним.

3 аналізу судової практики з відповідних справ можна зробити висновок про такі вимоги до задоволення позову власника (користувача) земельної ділянки щодо права власності на нерухоме майно, яке самочинно 
збудоване на ній: 1) відвід для цієї мети у встановленому порядку земельної ділянки власнику (користувачу) земельної ділянки (суд досліджує правовстановлюючі документи й з'ясовує цільове призначення земельної ділянки); 2) збудований об’єкт не порушує прав третіх осіб; 3) дотримані будівельні норми і правила (Держархбудінспекця подає відповідні висновки чи ці факти підтверджується будівельно-технічною експертизою); 4) самочинне будівництво було здійснено не позивачем, а іншою особою; 5) має бути встановлена відповідність об'єкта пожежним і санітарним нормам (надаються висновки уповноважених на те органів).

При цьому не може бути застосовано правила ст. 376 ЦК України під час вирішення справ за позовами: 1) про визнання права власності на самочинно переобладнані квартири в багатоквартирних будинках різних житлових фондів, оскільки такі правовідносини врегульовано іншими нормами законодавства, зокрема ст. 383 ЦК України та відповідними нормами Житлового кодексу України щодо власників квартир; 2) про визнання права власності на самочинно збудовані тимчасові споруди; 3) про визнання права власності на самочинно збудовані належності до основної речі (ганок, веранда, мансарда тощо) [2].

Проте у випадку, коли квартира в такому будинку розташована на першому поверсі й власник здійснив прибудову до неї з одночасним зайняттям частини прибудинкової земельної ділянки, спір повинен вирішуватися відповідно до правил ст. 376 ЦК України. Тобто облаштування балкону на фундаменті не може бути визнано переплануванням, а мають місце ознаки самочинного будівництва. А облаштування балкону, не пов'язане з використанням земельної ділянки, підпадає під ознаки перепланування (умови і порядок переобладнання, перебудови, перепланування будинків, жилих і нежилих приміщень у житлових будинках встановлені Правилами утримання жилих будинків та прибудинкових територій, затвердженими Наказом Державного комітету України з питань житлово-комунального господарства № 76 від 17 травня 2005 р.), тому під час вирішення таких спорів судам слід керуватися нормами ст. 383 ЦК України.

Суди під час розгляду справ про визнання права власності на самочинне будівництво повинні належним чином перевіряти, чи було питання оформлення права власності на самочинне будівництво предметом розгляду компетентного державного органу, рішення якого чи його відсутність давали б підстави говорити про наявність спору про право. Суд не повинен заміняти органи, які зобов'язані видавати дозволи на будівництво й узгоджувати забудови; визнання права власності на самочинне будівництво в судовому порядку має залишатися винятковим способом захисту права. Тому судам необхідно з'ясовувати, чи звертався позивач до компетентних органів із питанням узаконення самочинного будівництва, чи було відмовлено компетентними органами у вирішенні зазначеного питання [3].

У разі відсутності посилання на такі обставини або докази суд має відповідно до вимог ст. 121 ЦПК України залишити позовну заяву без руху 
та надати строк для усунення недоліків із наслідками, передбаченими ч. 2 ст. 121 ЦПК України.

Вирішуючи справи про самочинне будівництво об'єкта нерухомості, здійснене у разі відмови у видачі дозвільних документів, але з додержанням державних стандартів, норм і правил, місцевих правил забудови населених пунктів і порядку розгляду цих питань, суд має врахувати, що відмова у наданні дозвільних документів може бути оскаржена до суду заінтересованою особою у порядку адміністративного судочинства. Якщо такі дії у судовому порядку не оскаржено, це не є підставою для відмови в позові, проте суд під час розгляду справи має дати правову оцінку такій відмові, зокрема, за правилами ст. 212 ЦПК України [2].

Таким чином, право власності на самочинно збудоване нерухоме майно може бути за рішенням суду визнане лише у двох випадках: по-перше, за особою, яка здійснила самочинне будівництво на земельній ділянці, що не була їй відведена для цієї мети, за умови надання земельної ділянки у встановленому порядку особі під уже збудоване нерухоме майно; по-друге, за власником (користувачем) земельної ділянки, на якій здійснене самочинне будівництво, за відповідних умов. А саме: 1) особа - власник земельної ділянки не збігається з особою-забудовником (ця умова найчастіше порушується судами внаслідок неправильного тлумачення положень ст. 376 ЦК України, визнається право власності на самочинні будівлі за власниками земельних ділянок, навіть якщо ці власники є одночасно забудовниками); 2) це не порушує права інших осіб.

Частина 5 ст. 376 ЦК України у судовій практиці довгий час тлумачилась як можливість забудовника, якщо він $є$ власником земельної ділянки, визнати за ним право власності на об'єкт будівництва, що не випливає зі змісту ст. 376 ЦК України, а є лише спробою уникнути довготривалої процедури отримання усіх необхідних документів, пов'язаних із будівництвом нерухомих об'єктів.

Системний аналіз ч.ч. 3-5 ст. 376 ЦК України дозволяє зробити висновок, що законодавець мав на увазі можливість визнання права власності на об'єкт, якщо особа - власник (користувач) земельної ділянки не збігається з особою-забудовником. Тобто, якщо під уже збудований об'єкт забудовнику не вдалося відвести земельну ділянку чи змінити їі цільове призначення, власнику земельної ділянки дається право вимагати, щоб право власності на самочинно збудоване нерухоме майно було визнане за ним.

\section{Література}

1. Аналіз деяких питань застосування судами законодавства про право власності при розгляді цивільних справ [Електронний ресурс]. - Режим доступу : http://www.scourt.gov.ua/ clients/vsu/vsu.nsf / (documents)/1207B66D24762C1DC2257D0E004CC419.

2. Про практику застосування судами статті 376 Цивільного кодексу України (про правовий режим самочинного будівництва) : Постанова Пленуму Вищого спеціалізованого суду України з розгляду цивільних і кримінальних справ № 6 від 30.03.2012 р.

3. Про практику застосування судами законодавства під час розгляду цивільних справ про захист права власності та інших речових прав : Постанова Пленуму Вищого спеціалізованого суду України з розгляду цивільних і кримінальних справ від 21.12.2012 p. 


\section{А нот а ці я}

Голубева Н. Ю. Розгляд судами справ про визнання права власності на об'єкти самочинного будівництва. - Стаття.

Статтю присвячено дослідженню особливостей розгляду судами справ, пов'язаних 3 об'єктами самочинного будівництва. Проаналізовано специфіку відповідних справ, виявлено найбільш суттєві проблеми.

Ключові слова: самочинне будівництво, нерухомість, визнання права власності, об'єкти нерухомого майна, набуття права власності.

\section{Анн н т а ци я}

Голубева H. Ю. Рассмотрение судами дел о признании права собственности на объекты самовольного строительства. - Статья.

Статья посвящена исследованию особенности рассмотрения судами дел, связанных с объектами самовольного строительства. Проанализирована их специфика, выявлены наиболее существенные проблемы.

Ключевые слова: самовольное строительство, недвижимость, признание права собственности, объекты недвижимого имущества, приобретение права собственности.

\section{S u m m a r y}

Holubeva N. Yu. Consideration by courts of cases on recognition of ownership of objects of unauthorized construction. - Article.

The article deals with to the study of the peculiarities of consideration by courts of cases related to objects of unauthorized construction. Their specificity is analyzed, the most significant problems are revealed.

Key words: unauthorized construction, real estate, recognition of ownership, objects of real estate, acquisition of property rights. 